\title{
Graphical (Wr-Vr) and Numerical Diallel Analysis in Relation to Yield and its Components in Ridge Gourd (Luffa Acutangula Roxb.)
}

\author{
Jogendra Singh $^{1 *}$, A.D. Munshi ${ }^{1}$, A.K. Sureja ${ }^{1}$, Y.A. Lyngdoh ${ }^{1}$, \\ Seema Sangwan ${ }^{2}$ and B.S. Tomar ${ }^{1}$ \\ ${ }^{I}$ Division of Vegetable Science, ${ }^{2}$ Division of Microbiology, ICAR-Indian Agricultural \\ Research Institute, New Delhi, India \\ *Corresponding author
}

\section{A B S T R A C T}

Keywords

Ridge gourd, Luffa acutangula Roxb, Crop rotation, Heterosis

Article Info

Accepted:

17 October 2019

Available Online:

10 November 2019
A genetic analysis study was carried out for yield and its attributing characters in $7 \times 7$ half-diallel crosses of ridge gourd (Luffa acutangula Roxb.) at research farm of Division of Vegetable Science, Indian Agricultural Research Institute, New Delhi. The twenty one $F_{1}$ hybrids along with seven parental lines were grown in randomized block design in three replications. Estimation of genetic components of variation and graphical presentation deduced that most of the traits under study showed over-dominance and low narrow-sense heritability indicating predominance of non-additive gene action for the inheritance. Dominance effect $(\mathrm{H})$ was found to be higher than additive effect (D) and average degree of dominance was more than one for all the characters, thereby confirming the predominant role of non-additive gene action and commercial exploitation of heterosis for improvement of these traits. The graphical analysis further indicated the importance of over dominance and positions of parental arrays in the graphs were scattered suggesting parental diversity for the various traits studied.

\section{Introduction}

Ridge gourd (Luffa acutangula Roxb.), also known as Ribbed gourd, Chinese okra and Angled loofah (Whitaker and Davis, 1962), is a very popular low cost vegetable in the tropical and subtropical regions. It is an important component of crop rotation during spring-summer and kharif seasons in North India and is cultivated both on commercial scale and in kitchen garden. India is considered as the centre of origin of Luffa species and there is considerable amount of genetic diversity in Luffa with respect to 
different characters. The improvement programme of ridge gourd is based mainly on exploiting natural sources of germplasm by means of selection and hybridization followed by selection.

Development of high yielding varieties mainly depends upon genetically superior parents, coupled with suitable breeding methodology. To formulate any breeding method, it is imperative to have knowledge of gene action involved in inheritance of various traits. Selection and hybridization are the most important methods for crop improvement. The success of selection mainly depends upon the extent of genetic variability existing in a particular crop. Therefore, a higher genetic base should be utilized for faster and higher magnitude of success of breeding programme. Utilization of divergent germplasm in hybridization creates broad genetic base (Dubey and Ram, 2007; Biswas and Haque, 2007; Punia et al., 2013 and Al-Naggar et al., 2016). A detailed knowledge about the magnitude and nature of genetic variation in a specific population is of prime importance for prediction of the most effective breeding programme. In spite of exhibiting considerable amount of genetic diversity with respect to different characters, little attention has been given for improvement of this crop. Hence, an attempt was made to investigate the gene action (inheritance pattern) of yield and yield attributing traits.

\section{Materials and Methods}

The present investigation was carried out at the research farm of Division of Vegetable Science, Indian Agricultural Research Institute, New Delhi. Seven genetically diverse inbreds of ridge gourd viz., Pusa Nutan $\left(\mathrm{P}_{1}\right)$, DRG-7 $\left(\mathrm{P}_{2}\right)$, DRG-71 $\left(\mathrm{P}_{3}\right)$, Arka Sujat $\left(\mathrm{P}_{4}\right)$, Pusa Nutan $\left(\mathrm{P}_{5}\right)$, Swarna Uphar $\left(\mathrm{P}_{6}\right)$ and Co-1 $\left(\mathrm{P}_{7}\right)$ were crossed in $7 \times 7$ half-diallel mating. The resulting twenty one $F_{1}$ hybrids along with seven parental lines were evaluated in a randomized block design with three replications. The seeds were sown in rows of $2.5 \mathrm{~m}$ with $0.75 \mathrm{~m}$ spacing between the plants. All the recommended package of practice was followed to grow a successful crop. Out of 12 plants, 10 were used for taking observations. Observations on individual plant basis were recorded on nine quantitative characters, viz., days to first male flower anthesis, days to first female flower anthesis, days to first fruit harvest, fruit length $(\mathrm{cm})$, fruit diameter $(\mathrm{cm})$, average fruit weight $(\mathrm{g})$, number of fruits per plant, vine length $(\mathrm{m})$ and total fruit yield per plant (kg). Gene action was studied by Hayman's numerical and graphical approach (Wr-Vr graph) for diallel analysis.

\section{Results and Discussion}

The graphical analysis of the diallel crosses of ridge gourd was carried out with an objective to determine the allelic constitution of the parents used in the study. In the present investigation, additive-dominance model was adequate as obtained by significant difference of $\mathrm{b}(\mathrm{Wr}-\mathrm{Vr}$ ) from zero and approaching unity i.e. did not differ significantly from unity and also non significant value of $\mathrm{t}^{2}$ as suggested by Hayman (1954). On the basis of these results, it was assumed that epistasis is absent for all the traits under study.

The estimates of genetic components of variation and various statistical parameters for different characters were represented in Table 1. The dominance genetic components of variation $\left(\mathrm{H}_{1}\right)$ was recorded to be significant for all the character under study. Additive genotypic (D) variance was significant for days to first male flower anthesis, days to first fruit harvest, fruit length, fruit diameter, and number of fruits per plant. Thus, indicating the importance of both the additive and dominance components of variances for the expression of yield components. The value of 
$\mathrm{H}_{1}$ and $\mathrm{H}_{2}$ was more than $\mathrm{D}$, which signifies that dominant genes were more than additive genes. The overall dominance effects of heterozygous loci measured in terms of $h^{2}$ were highly significant and positive for all the traits under study except fruit length, suggesting that could be due to the presence of a considerable amount of dominant gene in the parental genotypes. The perusal of data reveals that average degree of dominance $\left(H_{1} / D\right)^{1 / 2}$ was greater than unity for all the characters under study indicating the preponderance of dominance component in the inheritance of these traits and degree of dominance was of over dominance. The proportion of genes with positive and negative effects $\left(\mathrm{H}_{2} / 4 \mathrm{H}_{1}\right)$ in the parents for all the studied traits was less than 0.25 , denoting asymmetry at the loci showing dominance. The more than unity value of proportion of dominant and recessive gene $\left(4 \mathrm{D} \mathrm{H}_{1}\right)^{1 / 2}+\mathrm{F} /$ $\left(4 \mathrm{D} \mathrm{H}_{1}\right)^{1 / 2}-\mathrm{F}$ for days to first female flower anthesis, days to first fruit harvest and fruit length indicated that these characters were controlled by more of dominant genes in the parents. In contrast, value less than unity suggested the presence of more number of recessive genes in the parents for that particular character. The degree of controlling gene reflected in the value of $\mathrm{h}^{2} / \mathrm{H}_{2}$ which revealed that more than a group of gene was controlling the inheritance of all the character studied. Low narrow sense heritability estimates for all the traits under study further confirmed the preponderance of non-additive gene action. The results are in conformity with the findings of Ahmed et al., 2006, Prabhakar 2008, Tyagi et al., 2010 and Singh et al., 2017 in ridge gourd.

The Wr-Vr graphs for yield and its attributing character have been presented in Figures (Fig. 1-9). Parental array points were scattered all along the regression line for all the traits studied which reflects the genetic diversity among the parents and also decides relative proportions of dominant and recessive alleles present in parents. For days to first male flower anthesis, regression line passed below the origin thus reveals the presence of over dominance gene action for the trait. The parent $\mathrm{P}_{2}$ and $\mathrm{P}_{1}$ occupied the closest position to the point of origin in $\mathrm{Wr}-\mathrm{Vr}$ graph indicating preponderance of dominant gene, while $\mathrm{P}_{7}$ possessed farthest followed by $\mathrm{P}_{5}$ suggesting recessive gene action for the expresssion of the trait. The parents $\mathrm{P}_{6}, \mathrm{P}_{3}$ and $\mathrm{P}_{4}$ were at intermediate position suggesting almost equal control of dominant and recessive gene. The regression line intercepted $\mathrm{Wr}$ axis below the origin thus indicating the presence of over dominance gene action for days to first female flower anthesis. The value of $\mathrm{H}_{1}$ was more than $\mathrm{D}$, which signifies that dominant genes were more than additive genes which is further confirmed by more than unity value of mean degree of dominance $\left(\mathrm{H}_{1} / \mathrm{D}\right)^{1 / 2}$ for this trait. The parents $\mathrm{P}_{3}, \mathrm{P}_{5}, \mathrm{P}_{1}$ and $\mathrm{P}_{2}$ had more number of dominant alleles while $\mathrm{P}_{7}, \mathrm{P}_{5}$ recorded maximum number of recessive alleles. The other parents $\mathrm{P}_{6}$ and $\mathrm{P}_{4}$ were conditioned by almost equal frequency of dominant and recessive alleles for the trait. It was reported that for days to first fruit harvest there is preponderance of over dominance gene action. The relative distribution of array points in $\mathrm{Wr}-\mathrm{Vr}$ graph showed that $\mathrm{P}_{1}$ possessed maximum frequency of dominant allele and parents $\mathrm{P}_{7}, \mathrm{P}_{5}$ and $\mathrm{P}_{4}$ had maximum frequency of recessive alleles while other parents $\left(\mathrm{P}_{2}, \mathrm{P}_{3}\right.$ and $\left.\mathrm{P}_{6}\right)$ were conditioned by almost equal frequency of dominant and recessive alleles.

For fruit length, the regression line in $\mathrm{Wr}-\mathrm{Vr}$ graph intercepted below the origin on $\mathrm{Wr}$ axis suggesting the presence of over dominance type of gene action which was further confirmed by more than unity value of $\left(\mathrm{H}_{1} / \mathrm{D}\right)^{1 / 2}$. 
Fig.1 Days to first male flower anthesis

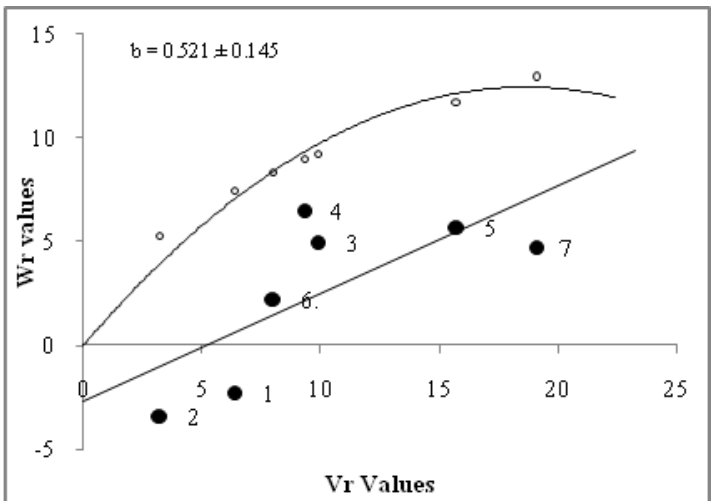

Fig.3 Days to first fruit harvest

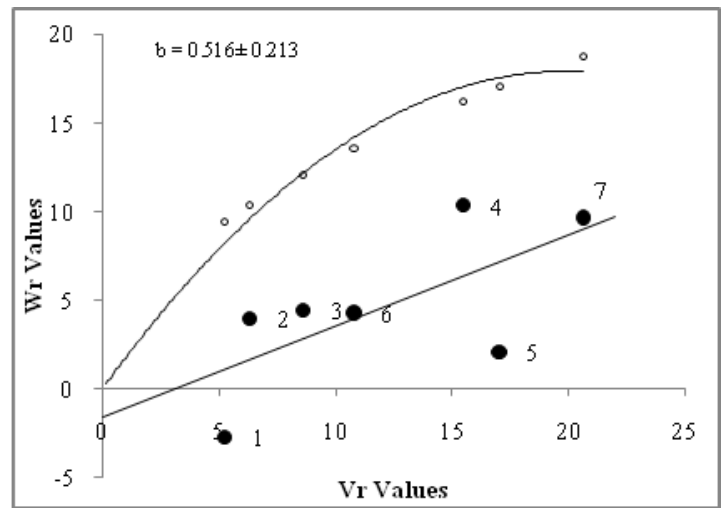

Fig.5 Fruit diameter

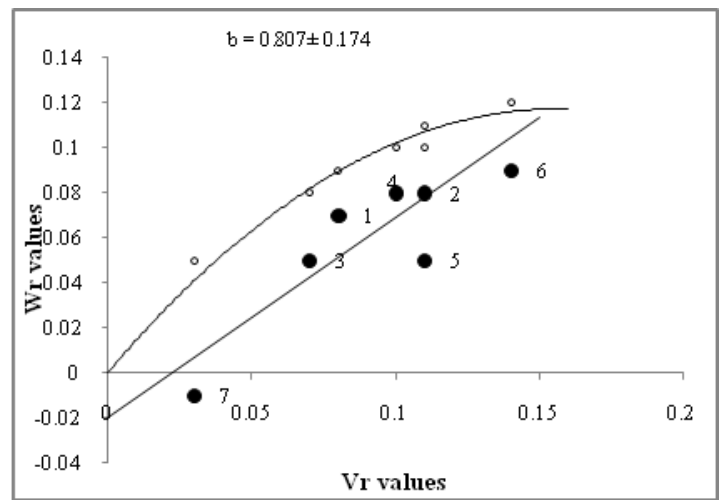

Fig.2 Days to first female flower anthesis

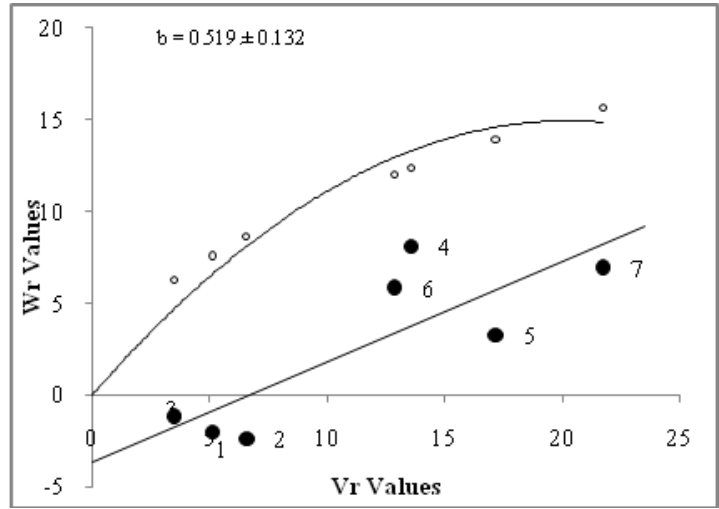

Fig.4 Fruit length

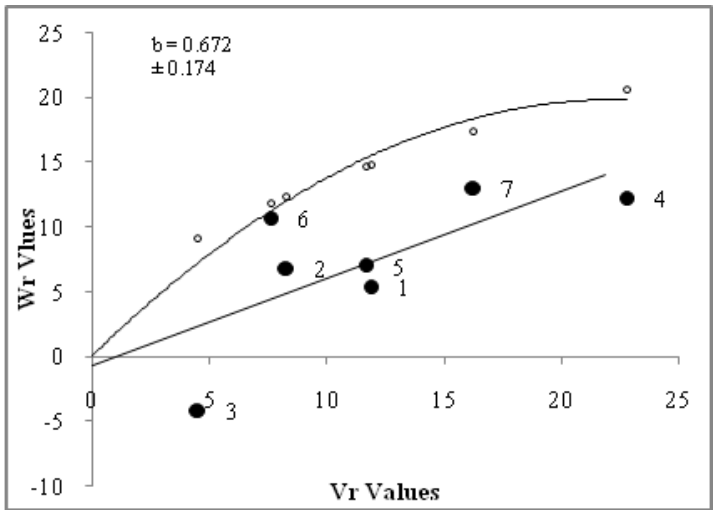

Fig.6 Average fruit weight

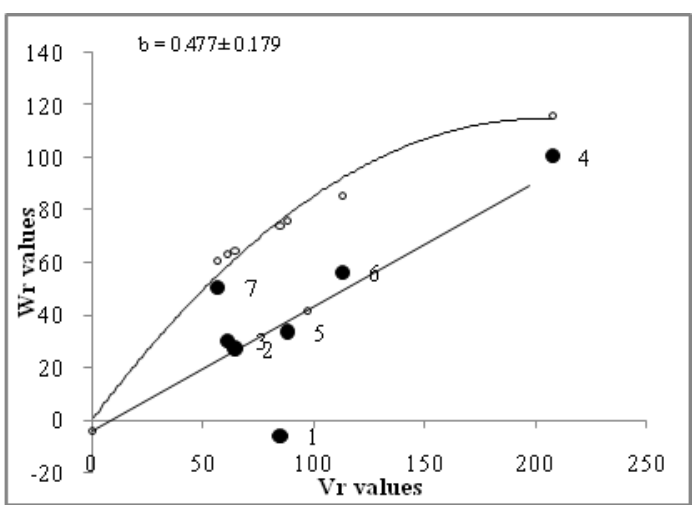


Fig.7 Number of fruit per plant

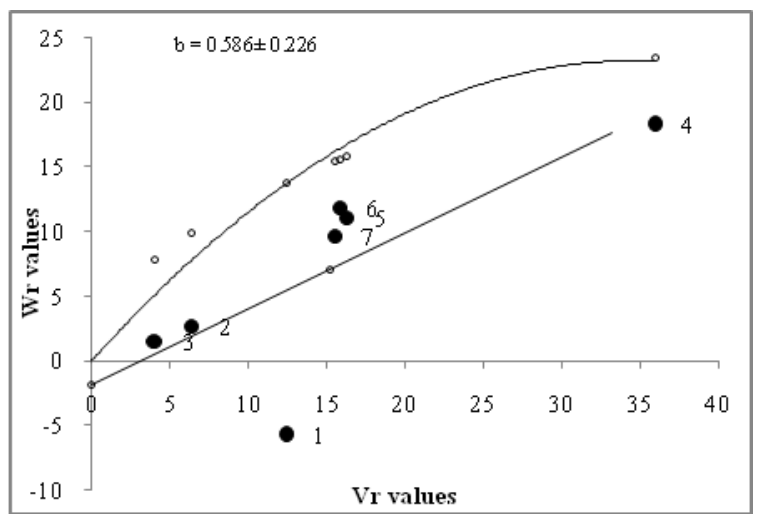

Fig.8 Vine length

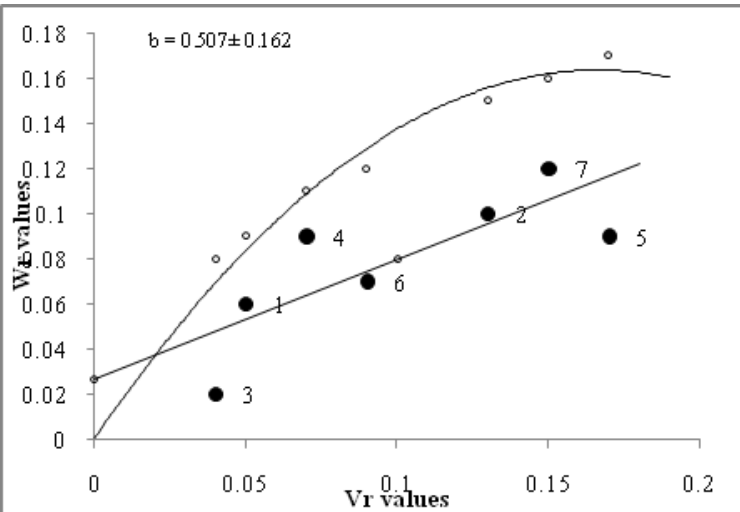

Fig.9 Total yield

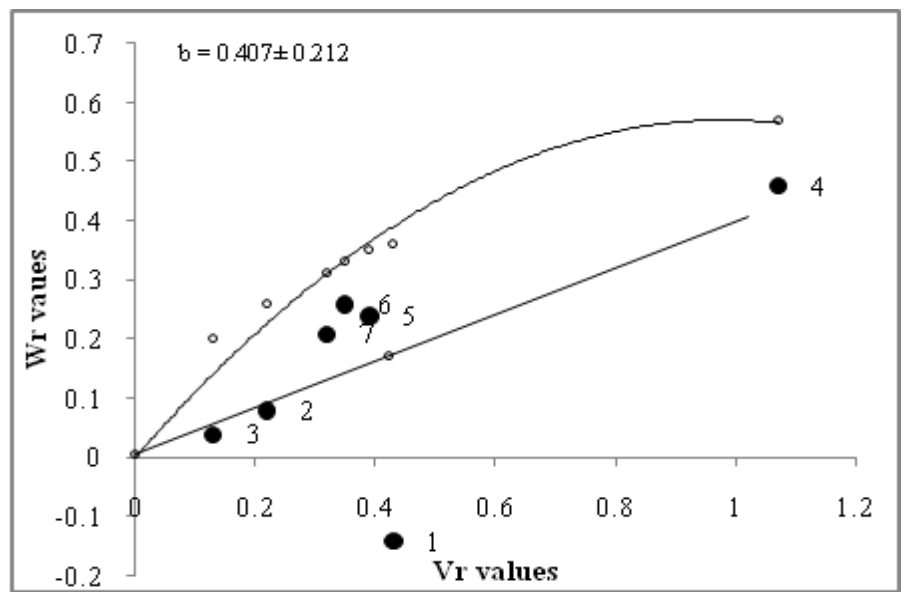


Table.1 Estimates of genetic components of variation for yield and its attributing characters in ridge gourd

\begin{tabular}{|c|c|c|c|c|c|c|c|c|c|}
\hline $\begin{array}{c}\text { Genetic } \\
\text { parameters }\end{array}$ & $\begin{array}{l}\text { Days to first } \\
\text { male flower } \\
\text { anthesis }\end{array}$ & $\begin{array}{l}\text { Days to first } \\
\text { female flower } \\
\text { anthesis }\end{array}$ & $\begin{array}{l}\text { Days to first } \\
\text { fruit harvest }\end{array}$ & $\begin{array}{l}\text { Fruit length } \\
\qquad(\mathrm{cm})\end{array}$ & Fruit diameter & $\begin{array}{l}\text { Average fruit } \\
\text { weight (g) }\end{array}$ & $\begin{array}{l}\text { Number of } \\
\text { fruit per } \\
\text { plant }\end{array}$ & $\begin{array}{l}\text { Vine length } \\
\text { (m) }\end{array}$ & $\begin{array}{l}\text { Total } \\
\text { yield } \\
(\mathrm{kg})\end{array}$ \\
\hline $\begin{array}{c}\text { (D) } \\
\text { Additive } \\
\text { effect }\end{array}$ & $5.78 \pm 3.20$ & $7.30 \pm 3.58^{* *}$ & $13.93 \pm 3.55 * *$ & $17.41 \pm 3.83 * *$ & $0.09 \pm 0.01 * *$ & $37.34 \pm 26.18$ & $13.05 \pm 5.11 *$ & $0.06 \pm 0.01$ & $\begin{array}{c}0.26 \pm 0 . \\
18\end{array}$ \\
\hline \multicolumn{10}{|l|}{$\begin{array}{c}(\mathbf{H}) \\
\text { Dominance } \\
\text { effect }\end{array}$} \\
\hline $\mathbf{H}_{1}$ & $29.01 \pm 7.70 * *$ & $31.41 \pm 8.63 * *$ & $34.95 \pm 8.54 * *$ & $26.65 \pm 9.22 * *$ & $0.26 \pm 0.03 * *$ & $209.27 \pm 63.04 * *$ & $41.71 \pm 12.30 * *$ & $0.15 \pm 0.06^{*}$ & $\begin{array}{c}1.19 \pm 0 . \\
42 * *\end{array}$ \\
\hline $\mathbf{H}_{2}$ & $26.43 \pm 6.79 * *$ & $29.55 \pm 7.60 * *$ & $31.48 \pm 7.52 * *$ & $20.67 \pm 8.12 *$ & $0.14 \pm 0.02 * *$ & $195.49 \pm 55.55^{* *}$ & $35.19 \pm 10.84 * *$ & $0.09 \pm 0.05$ & $\begin{array}{c}0.99 \pm 0 . \\
37 *\end{array}$ \\
\hline$h^{2}$ & $86.50 \pm 4.56^{* *}$ & $100.57 \pm 5.11^{* *}$ & $100.84 \pm 5.05^{* *}$ & $5.65 \pm 5.46$ & $0.82 \pm 0.02 * *$ & $738.21 \pm 37.31 * *$ & $124.08 \pm 7.28 * *$ & $0.31 \pm 0.03 * *$ & $\begin{array}{c}3.39 \pm 0 . \\
25 * *\end{array}$ \\
\hline $\begin{array}{c}\text { (F) Gene } \\
\text { distributio } \\
n\end{array}$ & $0.54 \pm 7.68$ & $1.80 \pm 8.60$ & $8.51 \pm 7.95$ & $-0.73 \pm 9.19$ & $-0.29 \pm 0.03 * *$ & $-76.44 \pm 62.82$ & $-0.80 \pm 12.26$ & $-0.20 \pm 0.06^{* *}$ & $\begin{array}{c}- \\
0.11 \pm 0 .\end{array}$ \\
\hline $\begin{array}{c}\text { (E) } \\
\text { Environme } \\
\text { ntal effect }\end{array}$ & $2.91 \pm 1.13^{*}$ & $3.98 \pm 1.27 * *$ & $3.08 \pm 1.25^{*}$ & $1.35 \pm 1.13$ & $0.18 \pm 0.00$ & $27.90 \pm 9.26$ & $2.28 \pm 1.81$ & $0.15 \pm 0.01 * *$ & $\begin{array}{c}0.03 \pm 0 . \\
06\end{array}$ \\
\hline$\left(H_{1} / D\right)^{1 / 2}$ & 2.24 & 2.08 & 1.58 & 1.24 & 1.69 & 2.37 & 1.79 & 2.73 & 2.13 \\
\hline $\mathrm{H}_{2} / \mathbf{4} \mathrm{H}_{1}$ & 0.23 & 0.24 & 0.23 & 0.19 & 0.13 & 0.23 & 0.21 & 0.15 & 0.21 \\
\hline $\begin{array}{c}\left(4 \mathrm{DH}_{1}\right)^{1 / 2}+ \\
\mathrm{F} /\left(4 \mathrm{DH}_{1}\right)^{1 / 2} \\
-\mathrm{F}\end{array}$ & 0.96 & 1.13 & 1.48 & 1.03 & 0.027 & 0.40 & 0.97 & 0.25 & 0.82 \\
\hline$h^{2} / \mathrm{H}_{2}$ & 3.27 & 3.40 & 3.20 & 0.27 & 5.87 & 3.78 & 3.53 & 3.44 & 3.42 \\
\hline $\begin{array}{l}\text { Heritabilit } \\
\text { y \% (ns) }\end{array}$ & 12.60 & 13.81 & 26.16 & 35.30 & 12.62 & 18.59 & 20.18 & 12.29 & 14.98 \\
\hline
\end{tabular}


The relative position of respective parents indicates maximum frequency of dominant alleles in $\mathrm{P}_{3}$ and recessive alleles in $\mathrm{P}_{4}$ while other parents were conditioned equally by dominant and recessive alleles. The over dominance type of gene action for fruit diameter inheritance which is confirmed as the regression line intercepted below the origin. The analysis of array points reveals that maximum number of parents exhibited receive alleles while only parent $\mathrm{P}_{7}$ possessed maximum dominant alleles for the trait. For average fruit weight regression line passed below the origin suggesting over dominance type of gene action which is further confirmed by more than unity $(2.37)$ value of $\left(\mathrm{H}_{1} / \mathrm{D}\right)^{1 / 2}$ where it is. The parents $\mathrm{P}_{3}, \mathrm{P}_{2}, \mathrm{P}_{1}$ and $\mathrm{P}_{7}$ had the maximum number of dominant alleles, being nearest to the origin. However, $\mathrm{P}_{4}$ carried maximum number of recessive alleles being farthest from the origin. The regression line intercepted the $\mathrm{Wr}$ axis below the origin indicating the preponderance of over dominance component of variation for the inheritance of number of fruits per plant. The analysis of relative distribution of array points in $\mathrm{Wr}-\mathrm{Vr}$ graph revealed that parents $\mathrm{P}_{3}, \mathrm{P}_{2}$ and $P_{1}$ possessed more number of dominant alleles and $\mathrm{P}_{7}$ exhibited maximum frequency of recessive alleles where as parents $\mathrm{P}_{7}, \mathrm{P}_{6}$, and $\mathrm{P}_{5}$ had equal frequency of dominant and recessive alleles for the trait. For vine length regression line passed above the origin thus suggesting almost partial dominance to control the inheritance of this trait. The distribution of parental arrays along the regression line indicates that parents $\mathrm{P}_{3}$, and $\mathrm{P}_{1}$ conditioned by more dominant alleles, parents $\mathrm{P}_{5}, \mathrm{P}_{2}$ and $\mathrm{P}_{7}$ possessed maximum recessive alleles and parents $\mathrm{P}_{4}$ and $\mathrm{P}_{6}$ had equal frequency of both dominant and recessive alleles. The regression line in $\mathrm{Wr}-\mathrm{Vr}$ graph intercepted $\mathrm{Wr}$ axis at the origin indicating complete dominance gene action for the inheritance of yield. The relative position of array points indicated that $\mathrm{P}_{3}, \mathrm{P}_{2}$ and $\mathrm{P}_{1}$ possessed maximum frequency of dominant alleles and $\mathrm{P}_{4}$ was predominated with recessive alleles while $\mathrm{P}_{7}, \mathrm{P}_{6}$ and $\mathrm{P}_{5}$ was conditioned by equal frequencies of dominant and recessive alleles for this trait.

Thus, graphical analysis of the experimental results depicted over dominance type of gene action for all the character studied except total yield and vine length where complete dominance and partial dominance type of gene action control the inheritance of the traits, respectively. These contradictory results between the approaches of as genetic components of variation and $\mathrm{Wr}-\mathrm{Vr}$ graph analysis could be ascribed to the presence of correlated gene distribution (Hayman 1954) The position of parental arrays in the graphs indicated that the parental line $\mathrm{P}_{3}$ had the maximum dominant gene for yield and its attributing characters viz., days to first female flower anthesis, fruit length, average fruit weight, number of fruits per plant and vine length among the genotypes studied.

The distribution of parents along the regression line indicates parental diversity. The importance of crosses between diverse parents which located away from the origin in $\mathrm{Wr}-\mathrm{Vr}$ graph analysis, subject to fulfilment of other criteria namely good GCA effect and the desirable mean values to produce desirable segregants were not neglected (Dubey and Ram, 2007). These results were also in conformity with the findings of Hedau and Sirohi (2004) and Tyagi et al., (2010) in ridge gourd.

The results of present investigation showed dominance and over-dominance gene actions for yield and its attributing traits in ridge gourd. Average degree of dominance was more than 1 and narrow sense heritability was found to be less than 0.5 for all the characters suggesting the preponderance of non-additive gene action. Thus, the predominance of nonadditive gene action for most of the important 
yield contributing characters suggested the importance of heterosis breeding to get higher yield advantage in ridge gourd.

\section{References}

Ahmed, M.A., Reddy, I.P. and Neeraja, G. 2006. Combining ability and heterosis for fruit yield and yield components in ridge gourd (Luffa acutangula). J. of Res. ANGRAU 34(1): 15-20.

Al-Naggar, A.M.M., Atta, M.M.M., Ahmed, M.A., and Younis, A.S.M. 2016. Numerical and graphical diallel analyses of maize (Zea Mays 1.) Agronomic and yield traits under well watering and water deficit at silking. Archives of Current Research International 5(3): 1-18.

Biswas, P. S. and Haque, M.E. 2007. Gene action of agronomic traits in rice (Oryza Sativa 1.) Bangladesh J. Pl. Breed. Genet., 20(2) : 31-36.

Dubey, R.K., Ram, H.H. 2007. Graphical analysis and numerical approach for a diallel analysis of yield components in bottle gourd (Lagenaria scieraria). Int. J. of Plant Breeding 1(1): 65-69.

Hayman, B.I. 1954. The theory and analysis of diallel crosses. Genetics 39: 789-809.

Hedau, N.K. and Sirohi, P.S. 2004. A diallel studies in ridge gourd [Luffa acutangula (Roxb) L.]. Orissa Journal of Horticulture., 32(1): 13-14.

Karmakar P. 2011. 'Studies on heterosis and inheritance of hermaphroditism in ridge gourd (Luffa acutangula Roxb.)'. Ph.D Thesis, ICAR-Indian Agricultural Research Institute, New Delhi.

Prabhakar, B.N. 2008. Combining ability and heterosis for fruit yield and yield components in ridge gourd (Luffa acutangula L.). J. of Res. ANGRAU 36(4): 24-32.

Punia, S., Ram, B., Koli, N.R., Ranwha, B.R. and Maloo, S.R. 2013. Genetic studies in relation to yield and its components in field pea (Pisum Sativum). Legume Res., 36(2): 98-104.

Singh, J., Munshi, A.D., Behera, T.K., Sureja, A.K., Srivastava, A. and Tomar, B.S. 2017. Heterosis for quantitative traits and mineral contents in ridge gourd (Luffa acutangula Roxb.). The Indian J.l of Agr. Sci. 87 (3): 379-84

Tyagi, S.V.S., Sharma, P., Siddiqui, S.A. and Khandelwal, R.C. 2010. Combining ability for yield and fruit quality in Luffa. Int.l J. of Veg. Sci. 16: 267-277.

Whitaker, T.W. and Davis, G.N. 1962. Cucurbits: Botany, Cultivation, and Utilization. World Crops Books, London, New York.

\section{How to cite this article:}

Jogendra Singh, A.D. Munshi, A.K. Sureja, Y.A. Lyngdoh, Seema Sangwan and Tomar, B.S. 2019. Graphical (Wr-Vr) and Numerical Diallel Analysis in Relation to Yield and its Components in Ridge Gourd (Luffa Acutangula Roxb.). Int.J.Curr.Microbiol.App.Sci. 8(11): 1869-1876. doi: https://doi.org/10.20546/ijcmas.2019.811.219 